\section{Parinaud's syndrome}

$\mathrm{H}$ enri Parinaud ${ }^{1}$ was a French ophthalmologist, born 1 May 1844, at Bellac, Haute-Vienne, the son of a locksmith. When Henri was 19, his father died; consequently he had to pay for his education and provide for his mother and brothers...he studied medicine at Limoges, and came to Paris in 1869.

He worked with the Red Cross during the outbreak of the Franco-Prussian war. His thesis, A study on the optic nerve in meningitis of infants, attracted Charcot's attention and he worked with him at the Salpêtrière, becoming Chef de Clinique under Xavier Galezowski. There he described optic neuritis, noting loss of colour vision in multiple sclerosis.

Parinaud was afflicted with indifferent health but published many papers, notably on stereoscopic vision and the visual cortex. He investigated ocular movements and strabismus, Parinaud's oculo-glandular syndrome (often caused by Bartonella henselae, responsible for cat scratch disease or tularaemia). His studies of lachrymal infections are well known.

He was to be a prime figure in French ophthalmology. Always absorbed in work, he conducted a free clinic to which students came from afar. But he remained a modest endearing man, who sought no public acclaim. Under the pseudonym of Pierre Erick, he composed several musical works. He developed bronchopneumonia and died 23 March 1905, in Paris.

Parinaud's syndrome (Paralysie des mouvements associés des yeux ${ }^{2}$ is a supranuclear paralysis of vertical gaze ${ }^{3}$ resulting from damage to the mesencephalon. Parinaud observed:

\section{"Dans l' étude des paralysies motrices de l'oeil, on semble admettre que la lésion est toujours périphérique...Mais, le plus souvent, la lésion est centrale..." [In the study of motor paralysis of the eye one seems to assume that the lesion is always peripheral...But, more often, the lesion is central...]}

He referred to Louis Foville's (1799-1878) case of facial paralysis and conjugate gaze palsy to the left and paresis on the right side, published 25 years earlier, when he postulated ${ }^{4}$ a centre for conjugate eye movements to the left in the left side of the pons, close to the abducens nucleus. Foville in turn referred to Edmé-Felix-Alfred Vulpian (1826-1887), who implicated an ascending tract in the pons contralateral to the oculomotor nucleus. Carl Wernicke (1848-1905) too, had demonstrated a slowly progressive tuberculoma in the pons causing conjugate gaze palsy to the left, and left peripheral facial paralysis. The centre, Wernicke postulated, was present bilaterally, near the abducens nucleus. ${ }^{5}$

Parinaud deduced there was a central system for the conjugate eye movements, and thought that the abducens nerve and the contralateral oculomotor nerve must have a connection in man, though he did not implicate the medial longitudinal bundle.

In his 10 case histories, he distinguished two groups: 1) the partial or dissociated paresis of both oculomotor nerves; and 2) conjugate eye movement disorders:
"Les mouvements associés des yeux sont de plusieurs espèces; ils sont parallèles ou non-parallèles. Dans les mouvements parallèles, les yeux se déplacent dans le même sens, par rapport à l'axe du corps...Les mouvements non parallèles ont pour but de modifier les rapports des axes entre eux, de manière à produire leur rencontre sur des objets fixés à des distances différentes..." [The associated eye movements are of many types; they are parallel or non-parallel. In the parallel movements the eyes move in the same direction in relation to the axis of the body... The aim of the non-parallel movements is to modify the relation of the [ocular] axes to one another in such a way that they come together on fixed objects at different distances...]

In a paper in Brain, ${ }^{6}$ Paralysis of the movements of convergence of the eyes, he described convergence disorders in more detail. Patients, observation IV and observation V, in his series are of interest: a 67 year old man could not look upward or downward except for a slight movement upward with the right eye, resulting in diplopia; and a 20 year old woman was unable to look upward, she became nauseated and complained of headache when she tried to do so. Convergence was nil in both patients and, as far as mentioned, the pupils did not react to light. Horizontal eye movements were normal.

He then presented a simple scheme combining these three varieties of the same paralysis: paralysis of downward movements, paralysis of upward movements, paralysis of all vertical movements, all three in combination with convergence paralysis. However, he failed to localise the lesion precisely, referring to the lack of contemporary anatomical knowledge.

We now know that Parinaud's syndrome affects both voluntary saccades and pursuit movements, with preservation of vestibulo-ocular or oculocephalic reflexes in most cases. ${ }^{7}$ The critical lesion lies in the efferent paths of the rostral interstitial nuclei of the medial longitudinal fasciculus. ${ }^{3}$

J M S Pearce J M S Pearce, 304 Beverley Road Anlaby, East Yorks HU10 7BG UK; jmspearce@freenet.co.uk

\section{References}

1 Ouvrier R. Henri Parinaud and his syndrome. Med J Austr 1993;158:71 1-14.

2 Parinaud H. Paralysie des movements associés des yeux. Archives de Neurologie 1883;5:145-72.

3 Pierrot-Deseilligny C, Chain F, Gray M, et al. Parinaud's syndrome. Brain 1982;105:667-96.

4 Foville ALF. Note sur une paralysie peu connue des certains muscles de l'oeil et sa liaison avec quelques points de l'anatomie et la physiologie de la protubérance annulaire. Bull Soc Anat 1858;33:393-405.

5 Wernicke C. Ein fall von Ponserkrankung. Arch Psychiat (Berlin) 1877;7:513-38.

6 Parinaud $\mathrm{H}$. Paralysis of the movements of convergence of the eyes (trans Henry Juler). Brain 1886;9:330-41

7 Cogan DG. Neurology of the ocular muscles. Springfield, Illinois: Charles C Thomas, 1956:123-4. 